\title{
An Analysis of the Relationship between Attitudes towards Teaching and Professionalism in Teaching
}

\section{Análisis de la relación entre actitudes hacia la docencia y profesionalismo en la docencia}

Fahrettín Korkmaz (1) https://orcid.org/0000-0001-9644-3276

Serkan Unsal (2) https://orcid.org/0000-0003-0367-0723

(1) Ministry of National Education

(2) Kahramanmaras Sutcu Imam University

(Received: June 10, 2017; accepted for publishing: October 20, 2017)

How to cite: Korkmaz, F. y Unsal, S. (2020). An analysis of the relationship between attitudes towards teaching and professionalism in teaching. Revista Electrónica de Investigación Educativa, 22, e05, 1-15. https://doi.org/10.24320/redie.2020.22.e05.2042

\begin{abstract}
This research aims to identify teachers' views about the relationship between teachers' professionalism and their attitudes towards the profession. The study follows a quantitative research design and is descriptive in its relational model. Research data was collected through occupational professionalism and teaching profession attitude scales. In the data analysis process, frequency ( $F$ ), percentage (\%), and arithmetic average $(\overline{\mathrm{X}})$ were first calculated in order to reveal teachers' attitudes towards their profession and professionalism. In addition, a Pearson correlation analysis and regression analysis were used to determine the relationship between teachers' attitudes towards the teaching profession and their occupational professionalism. The analyses revealed a medium, significant and positive relationship between teachers' attitudes towards the teaching profession and levels of occupational professionalism. The regression analysis was conducted so as to identify how teachers' attitudes towards the teaching profession predict their level of occupational professionalism, shown by the effect of teachers' professional attitude scores $(F(1.257)=37.08, p=.000)$ on their occupational professionalism scores. The research findings also show that professional attitude scores predict $13 \%$ of total variance related to occupational professionalism. This most likely suggests that teachers' professional attitude is a remarkable predictor of their occupational professionalism.
\end{abstract}

Keywords: Teacher attitudes, professionalism, teaching profession.

\section{Resumen}

Este estudio busca identificar las percepciones de los docentes en cuanto a la relación entre el profesionalismo de los docentes y sus actitudes hacia la profesión. El estudio es de diseño cuantitativo y descriptivo en su modelo relacional. Los datos se recabaron mediante escalas de profesionalismo laboral y actitud hacia la profesión docente. El proceso de análisis de datos consistió en calcular primero la frecuencia ( $\mathrm{f})$, el porcentaje (\%) y la media aritmética $(\overline{\mathrm{X}})$ para conocer las actitudes de los docentes hacia su profesión y su profesionalismo. Por otra parte, se empleó un análisis de correlación de Pearson junto con un análisis de regresión para determinar la relación entre las actitudes de los docentes hacia la profesión docente y su profesionalismo laboral. Los análisis mostraron una relación media, significativa y positiva entre las actitudes de los docentes hacia la profesión docente y niveles de profesionalismo 
laboral. El análisis de regresión se llevó a cabo para identificar cómo las actitudes de los docentes hacia la profesión docente predicen su nivel de profesionalismo laboral, lo cual se refleja en el efecto de las puntuaciones de la actitud profesional $(F(1.257)=37.08, p=.000)$ sobre las de profesionalismo laboral. Los resultados de la investigación también muestran que las puntuaciones de actitud profesional de los docentes explican el $13 \%$ de la varianza total en relación con el profesionalismo laboral. Lo anterior indica muy probablemente que la actitud profesional de los docentes es un excelente predictor de su profesionalismo laboral.

Palabras clave: Actitud del docente, profesionalismo, docente.

\section{Introduction}

The relevance of teacher professionalism stems from the fact that the teaching profession is an important factor affecting the quality of education and community life (Çetin \& Doğan, 2018; Snoek et al., 2011; Unsal, Agcam, \& Korkmaz, 2017). Professionalism has various definitions depending on the basic values of the field and the work performed. The concept of professionalism in terms of education has meant different things to different people at certain times (Robson, 2006). Depending on the context, the concept of professionalism is likely to evoke different images in the human mind and have multiple definitions (Tichenor \& Tichenor, 2005).

Adiguzel, Tanriverdi, and Ozkan (2011) define professionalization as a service carried out by those who undergo training in their own fields and are supported by professional organizations, while Hanlon (1998) postulates that professionalism refers to variability rather than a concrete fact. Therefore, the structure of professionalism varies across values and qualities.

Having noted the long historical background of professionalism, Evetts (2012) states that professionalism is evaluated as a professional or normative value at the outset and is considered to be a worthwhile incentive for employees; more recently, it has been interpreted as a discourse that merges and expands with professional values and ideological interpretations. Adiguzel et al. (2011) report that rapid changes and developments in today's climate necessitate occupational professionalization. A number of criteria must be met for professionalism, including:

1. The presence of associations or professional organizations related to the profession;

2. The freedom to act regardless of working conditions;

3. Long-term, comprehensive and effective education;

4. Performance of the service offered in consideration of social interests;

5. Having the qualifications and competencies required to work in the chosen field;

6. The obligation to comply with the stated rules of the profession;

7. Being open to regular studies and innovations achieved with scientific methods and techniques (Adiguzel et al., 2011: 239).

Gökcora (2005) stresses that being professional in a job means knowing the finest details and applying them. The more complex the task, the more important it is to become professional. In other words, professionalism requires performing a job with as few mistakes as possible. Professional qualities include knowing one's boundaries in the profession, improving oneself professionally, teamwork skills, professional knowledge, respect for colleagues, and a sense of responsibility.

Carr (2005) defines professionalism as a special category of occupations, and provides five criteria for professionalism: professions provide an important public service, involve theoretical and practical expertise, have an ethical dimension, require a certain organization and regulation for the purpose of discipline and employment, and have a higher degree of individual autonomy so that professionals can give their decisions independently as practitioners. These criteria are entirely applicable in some occupations (such as doctors and lawyers), whereas only one or some of these criteria apply in professions such as teaching. 


\subsection{Profesionalism in Teaching}

Tichenor and Tichenor (2005) report numerous descriptions of professionalism in teaching, yet few studies have examined what teaching professionalism means on a practical level. Likewise, Snoek (2010) states that teachers mostly face high social expectations with regard to their professionalism; thus, professionalism represents a challenge in teaching.

Teacher professionalism traditionally refers to an understanding that protects teachers from external attacks on their fields and expertise. This also implies that members of professions are in a semiautonomous position within their own expertise and perspective. At the same time, the emphasis on professionalism in teaching comes to the fore within the context of "neoliberal education reforms", in contrast to the traditional sense. Teacher professionalization can be conceived as the solution to all problems with the application of new managerialism, which makes teachers responsible for shortcomings in education. This perspective is disciplined and controllable. It prescribes measuring practices through external accountability mechanisms such as standards, performance indicators, and productivity (Unal, 2011).

Snoek et al. (2011) point out that the concept of "profession" is mostly used for high-status occupations such as doctors, lawyers, and architects despite being of English origin, and, moreover, that teaching is subject to greater control from state bureaucracy and the state hierarchical system, and has far less autonomy. Teaching is described by different experts as a semi-profession or a sub-profession, rather than a real profession like medicine, law, and architecture. Carr (2005) notes that doctors and lawyers are more autonomous in terms of occupational professionalism.

According to a 2016 OECD report (OECD, 2016), teacher autonomy, professional teaching knowledge, and professional cooperation are significant characteristics of professionalism in teaching as it has been examined worldwide. Similarly, Tichenor and Tichenor (2005) identify five major aspects of professionalism in teaching. These are listed as character, commitment to change and continuous improvement, subject knowledge, pedagogical knowledge, and working relationships and obligations beyond the classroom.

Professionalism consists of three components: autonomy, professional knowledge, and responsibility. Under the autonomy component, it should be discussed whether teaching is a profession or not, and how teachers make decisions in terms of the knowledge base they must be able to use. With respect to professional knowledge, knowledge about practicing law and nursing is learned after being put into practice, while teachers mostly face the question of how to first learn the knowledge and then teach it professionally. On the other hand, responsibility is closely related to the concept of accountability, but is only possible with autonomy. Teachers' roles are evident within the framework of legislation, yet their responsibilities may vary based on political and social changes (Robson, 2006; Snoek, 2010).

1. Snoek (2010) lists the following characteristics of teacher professionalism:

2. Professional autonomy, teachers' control over their own work;

3. Willingness to become involved in entry to the profession;

4. Participation in professional societies;

5. A focus on professional commitment and honesty;

6. Public accountability for outcomes of professional performance;

7. A strong knowledge base that underpins professional activities;

8. Lifelong development of the members of the profession;

9. Collaboration with colleagues and stakeholders;

10. Support for the innovation of the profession. (Snoek, 2010: 9) 
Increasing levels of professionalization of teachers have had a positive effect on their teaching practices in class (Cohen \& Hill, 2000), teaching skills, and management strategies (Guskey, 1986). Cansoy and Parlar (2017) have emphasized that professional behaviors among teachers significantly contribute to the effective planning and implementation of teaching and training for successful students.

\subsection{Attitude towards the Teaching Profession}

Different researchers have offered different definitions of the concept of attitude (Ozkan, 2012). Smith (1968) defines attitude as a tendency attributed to an individual and forming a regular pattern of the individual's thoughts, emotions, and behaviors in relation to a psychological object (Akt et al., 2014, p. 130); Latchanna and Dagnew (2009) identify attitude as an important concept in understanding human behavior and a complex mental process involving beliefs and emotions. Tufan and Gudek (2008) explain attitude as a condition that is learned in order to react to humans, events, and opinions in a desired or undesired way; it is defined as a mental state that guides an individual's behavior. Attitude is also described as a learned tendency to learn behavior that is understood by making inferences with reference to behaviors that are not directly observed (Demirel \& Un, 1987; Kagıtcıbasi \& Cemalcilar, 2014). Anderson (1988) clarifies that attitude is a structure that guides human behaviors and is composed of three basic elements: cognitive, emotional, and behavioral. This makes it difficult for any attitude to be fully understood.

Kaya and Buyukkasap (2005) have stated that one's attitude towards the profession will likely affect the end product positively or negatively, and a person who feels dissatisfied with his or her job may not perform as desired. Likewise, Rimm-Kaufman and Sawyer (2004) put great emphasis on the close relation between teachers' behaviors and practices in the classroom and their attitudes and priorities. Can (2010) found a significant relationship between teachers' attitudes towards the teaching profession and achievements in teaching.

The teaching process and teachers' performance are substantially influenced by attitudes towards the profession (Agcam \& Babanoglu, 2016). Teachers with positive attitudes towards their profession perform better in the teaching-learning process, which in turn motivates them. This increases teachers' participation in academic activities in their schools and enables them to communicate more effectively with colleagues, students, and parents. Professional attitude may be regarded as a significant predictor of an effective teaching process.

\subsection{The Relationship between Professionalism in Teaching and Attitude towards the Teaching Profession}

Professionalism in education is a profound and complex issue (Helterbran, 2008). It is an oft-discussed but little understood aspect of teachers' work worldwide (McCulloch et al., 2000). A close relationship has been reported between professionalism in teaching and attitude towards the teaching profession (Snoek, 2010). Snoek (2010) argues that the three basic features of knowledge, skills, and attitudes may contribute to teacher professionalism. Teachers who are professionalized are expected to display various attitudes such as a willingness to train students, readiness to increase their professional knowledge in cooperation, sensitivity to innovations and developments in teaching, and a disposition to follow developments related to the teaching profession. Rimm-Kaufman and Sawyer (2004) suggest that as the level of teachers' professionalism increases, they are more likely to develop positive attitudes towards their colleagues, students, and the school. Kramer (2003) classifies teacher professionalization in three critical categories: attitude, behavior, and communication. These cover virtually the entire professional life of a teacher and characterize teachers' behaviors and character with students, parents, and colleagues. For instance, a teacher who has had a rough day must not reflect this in the classroom, as one requirement of professionalism.

Bumen and Ozaydin (2013) have evaluated many studies on the concept of attitude towards the teaching profession and attitude scales in Turkey since the 1980s, which have made it possible to determine the 
characteristics of successful teachers and the problems that teachers experience. A literature review reveals numerous studies on attitude toward the teaching profession.

These studies include work on the relationship between attitudes towards the teaching profession and teaching motivation by Ayik and Atas (2014); a study on the relationship between attitudes towards the teaching profession and teaching motivation, by Bumen and Ozaydin (2013); an examination of the attitudes of students at the School of Science and Literature towards the teaching profession in terms of different variables, by Demircioglu and Ozdemir (2014); a study of the validity and reliability of an attitude scale towards the teaching profession, by Ustuner (2006); a study on the attitudes of the students of the Necatibey School of Education toward the teaching profession, by Terzi and Terzi (2007); a study of prospective teachers' attitudes towards the teaching profession and their self-efficacy beliefs, by Demirtas et al. (2011); a study about attitudes toward the teaching profession and teacher selfefficacy beliefs of students in teacher training programs by Yakar and Yelpaze (2019); an analysis of the attitudes towards the teaching profession of prospective teachers who enrolled in a teacher training program, by Ozkan (2012); and a determination and comparison of competency perceptions and attitudes of prospective physical education and other pre-service teachers, by Sandikci and Oncu (2013).

Ayik and Atas (2014) found a positive relationship between prospective teachers' teaching motivation and their attitudes towards the teaching profession, and that prospective teachers' attitudes towards the teaching profession are a significant predictor of their teaching motivation. A similar finding was reported in Ahmad et al. (2013), in that there is a positive relationship between teachers' attitudes towards the teaching profession and their success.

No research on the relationship between attitudes towards the teaching profession and professionalism was found in the literature. This study aims to examine this relationship in terms of different variables. The research findings are expected to contribute to the field and the literature.

Yirci (2017) emphasizes that professionalization depends on teachers' competencies, their attitudes towards the profession, and their relationships with other teachers, management, and students. Evans (2011) states that teacher professionalism consists of three dimensions: the behavioral dimension of teacher proficiency and learning-enhancing activities; the attitude dimension, which relates to teachers' attitudes towards their profession; and the intellectual dimension, which involves teacher knowledge.

There is a relationship between professionalism and attitude towards the profession, which this research will examine to explore how teacher attitude towards the profession, which is an independent variable, predicts occupational professionalism.

The discovery of the relationship between teachers' occupational professionalism and their attitudes towards the profession is thought to be helpful for policymakers to develop regulations for teachers' occupational professionalism. Koşar (2015) suggests that it would be useful to examine the institutional and personal factors that determine teachers' professional behavior in order to better understand this behavior. In this regard, this study is expected to make a significant contribution to understanding the factors that affect professionalism.

\subsection{Research Aims}

This research aims to identify teachers' views about the relationship between teachers' professionalism and attitudes towards the profession. Accordingly, the study sought answers to the following questions:

1. How are levels of teachers' attitudes towards the teaching profession distributed?

2. How are the levels of teachers' occupational professionalism distributed?

3. Is there a significant relationship between teachers' occupational professionalism and their attitudes towards the teaching profession? 
4. Are teachers' attitudes towards the teaching profession a significant predictor of occupational professionalism?

\section{Method}

This section presents the research model, population and sample, data collection tools, and data analysis. In order to explore teachers' attitudes towards their profession and their occupational professionalism, this study was designed in a relational model that describes a currently existing situation.

The study aims to determine teachers' attitudes towards their profession and their occupational professionalism based on the views of teachers located within the province of K. Maraş in Turkey during the 2016-2017 academic year. To this end, the study follows a quantitative research design and is descriptive in its relational model. Relational models are research models that describe individuals, events or objects in their own circumstances and are used to determine the relationships between variables and the existence and/or degree of changes between two or more variables (Karasar, 2005; McMillan \& Schumacher, 2006). The main objective of the study is to examine the predictive effect of teachers' professional attitudes on their occupational professionalism through the use of the relational model.

The research was carried out with teachers working at schools located within the province of K. Maraş in Turkey. The sample consisted of 292 teachers in total, selected by simple random sampling, meaning that each unit has an equal chance of being selected for the sample (Balci, 2001; Karasar, 2005). Table I shows the participants' demographics.

Table I. Participant Demographics

\begin{tabular}{l|l|r|r}
\hline Demographic Features & $\mathbf{n}$ & $\mathbf{\%}$ \\
\hline \multirow{2}{*}{ Gender } & Male & 165 & 57 \\
& Female & 125 & 43 \\
& Total & 290 & 100 \\
\hline \multirow{2}{*}{ Schooling } & Undergraduate & 245 & 85 \\
& Postgraduate & 45 & 15 \\
& Total & 290 & 100 \\
\hline \multirow{5}{*}{ Seniority } & $0-5$ & 75 & 25 \\
& $6-10$ & 55 & 19 \\
& $11-15$ & 44 & 15 \\
& $16-20$ & 62 & 21 \\
& 20 and over & 54 & 11 \\
& Total & 290 & 100 \\
\hline \multirow{5}{*}{ Level taught } & Elementary & 96 & 33 \\
& Middle school & 112 & 40 \\
& High school & 82 & 28 \\
\hline Total & & 290 & 100 \\
\hline
\end{tabular}

The table shows that 165 teachers (57\%) were men and 125 (43\%) were women, and 245 (85\%) had a bachelor's degree while $45(15 \%)$ had a graduate degree. Also, 75 teachers (25\%) had 1-5 years of experience, 55 (19\%) had 6-10 years, 44 (15\%) had $11-15$ years, 62 (21\%) had $16-20$ years; and $54(11 \%)$ had 20 or more years' experience. As far as the level of education taught was concerned, 96 (33\%) of teachers worked in elementary school, 112 (40\%) in middle school, and 82 (30\%) in high school.

\subsection{Data Collection Tools}

The study employed two data collection tools that were applied simultaneously. It was decided to use the teaching profession attitude scale to determine teachers' attitudes towards the teaching profession and 
the occupational professionalism scale to reveal what kind of occupational professionalism the teachers exhibit. The relationship between teachers' professional attitudes and their occupational professionalism was revealed using both scales.

The Teaching Profession Attitude Scale developed by Çetin (2006) was employed to determine teachers' attitudes towards their profession. The tool comprises 35 items and 3 factors: love, value, and harmony. The study also used the Occupational Professionalism Scale, developed by Yilmaz and Altinkurt (2014), with a view to identifying teachers' professionalism. The scale contains 24 items and 4 factors (personal development, professional awareness, contribution to organization, and emotional labor). Reliability coefficients for both scales are presented in Table II.

Table II. Cronbach's alpha reliability coefficients of teachers' professional attitude and occupational professionalism scales

\begin{tabular}{|c|c|c|c|c|c|}
\hline \multicolumn{3}{|c|}{ Teaching Profession Attitude Scale } & \multicolumn{3}{|c|}{ Occupational Professionalism Scale } \\
\hline Factors & $\begin{array}{l}\text { Obtained } \\
\text { from } \\
\text { original } \\
\text { scale }\end{array}$ & $\begin{array}{c}\text { Obtained } \\
\text { from the } \\
\text { current } \\
\text { study }\end{array}$ & Factors & $\begin{array}{l}\text { Obtained } \\
\text { from } \\
\text { original } \\
\text { scale }\end{array}$ & $\begin{array}{c}\text { Obtained } \\
\text { from the } \\
\text { current } \\
\text { study }\end{array}$ \\
\hline Love & $a=.95$ & $a=.90$ & $\begin{array}{l}\text { Personal } \\
\text { Development }\end{array}$ & $a=.79$ & $a=.75$ \\
\hline Value & $a=.81$ & $a=.79$ & $\begin{array}{l}\text { Professional } \\
\text { Awareness }\end{array}$ & $a=.74$ & $a=.76$ \\
\hline Harmony & $a=.76$ & $a=.74$ & $\begin{array}{l}\text { Contribution to } \\
\text { Organization }\end{array}$ & $a=.86$ & $a=.84$ \\
\hline - & & & Emotional Labor & $a=.80$ & $a=.78$ \\
\hline Total & $a=.95$ & $a=.91$ & Total & $a=.90$ & $a=.88$ \\
\hline
\end{tabular}

The Cronbach's alpha reliability coefficients for the Occupational Professionalism Scale were determined to be 0.79 for personal development, 0.74 for professional awareness, 0.86 for contribution to the organization; 0.80 for emotional labor, and 0.90 for the overall scale. The Cronbach's alpha values of the factors for this study are as follows: personal development, 0.75; professional awareness, 0.76; contribution to the organization, 0.84 ; emotional labor, 0.78 ; overall scale, 0.88 . For the factors of the Teaching Profession Attitude Scale, the coefficients were found to be $a=.95$ for love, $a=.81$ for value, and $a=.76$ for harmony. The Cronbach's alpha reliability coefficient for the overall scale was determined to be $a=.95$. In the present study, the Cronbach's alpha values of the factors are as follows: love $a=.90$, value $a=.79$, harmony $a=.76$, and the overall scale $a=.95$.

\subsection{Data Analysis}

The research data was analyzed based on frequency (f), percentage (\%), and arithmetic mean $(\bar{X})$ so as to reveal teachers' views on the relationship between their attitudes towards the teaching profession and occupational professionalism. This relationship was also determined using a Pearson's bidirectional correlation analysis and regression analysis. Regression analysis is a statistical method used to explain the relationship between a dependent variable and one or more independent variables (Buyukozturk, 2010; Cokluk et al., 2010). Findings were tested at the $p<.05$ significance level. The study confirmed whether the dependent and independent variables exhibited normal distribution as a requirement for regression analysis (Figures 1). 

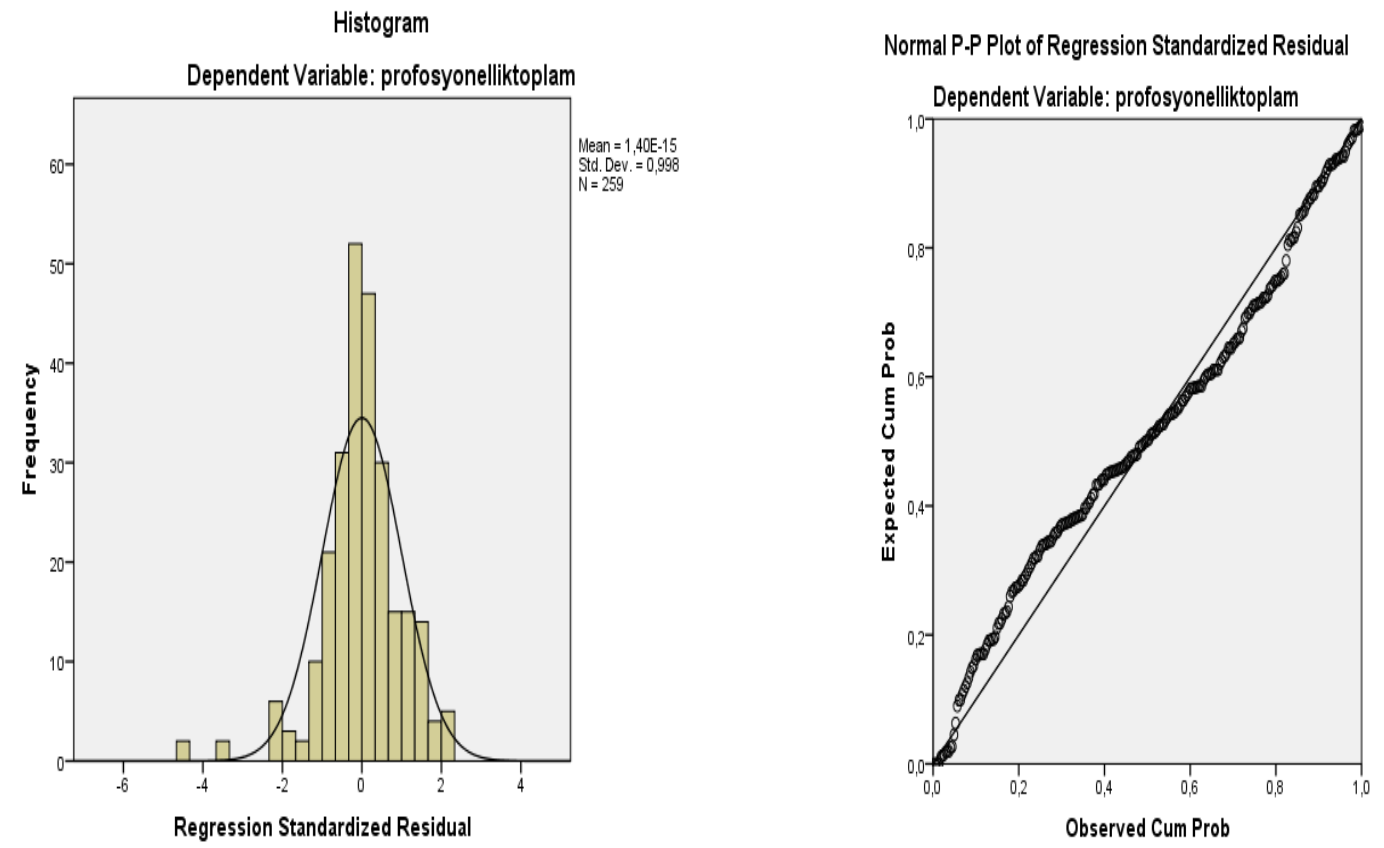

Figure 1. Histogram and plot values

Figure 1 show that the curve connecting the peak points is a symmetrical bell curve, and that the actual values overlap with the values of the theoretical distribution, resulting in a 45-degree angle. As a result of the analyses, both figures demonstrated normal distribution (Buyukozturk, 2010; Can, 2014).

Both researchers hold a doctoral degree from the Department of Curriculum and Instruction, and have conducted various studies on teacher training. They were actively involved in the data collection and analysis process. At the data analysis stage, the role of researchers is to report the collected data and evaluate its meaning in the context of the research question.

\section{Findings}

\subsection{Findings Regarding the First Two Research Questions}

The arithmetic mean and standard deviation values from the analysis of teachers' attitudes towards the teaching profession and occupational professionalism are displayed in Table III and interpreted. 
Table III. Arithmetic mean and standard deviation values of factors related to attitude towards the profession and occupational professionalism

\begin{tabular}{l|l|c|c|c}
\hline \multicolumn{1}{c|}{ Scales } & \multicolumn{1}{|c|}{ Dimensions } & $\mathrm{n}$ & $\overline{\mathrm{X}}$ & $\mathrm{s}$ \\
\hline \multirow{4}{*}{ Attitude Scale } & Love & 290 & 3.74 & .71 \\
& Value & 290 & 4.42 & .53 \\
& Harmony & 290 & 3.64 & .87 \\
& Attitude Total & 290 & 3.88 & .62 \\
\hline \multirow{5}{*}{ Professionalism } & Professional Awareness & 290 & 4.32 & .70 \\
Scale & Emotional Labor & 290 & 4.12 & .74 \\
& Contribution to the Organization & 290 & 3.74 & .72 \\
& Personal Development & 290 & 3.48 & .73 \\
& Professionalism Total & 290 & 3.86 & .60 \\
\hline
\end{tabular}

The teachers' responses for the Teaching Profession Attitude Scale in Table III show that the dimension with the highest average is value $(x=4.04)$ while harmony has the lowest average $(x=3.64)$. Based on the standard deviations, the dimension that is most homogeneously distributed is value $(s=.65)$, whereas the most heterogeneous distribution is that of harmony $(s=.77)$. The average of teachers' views for the overall attitude scale is "I agree" ( $x=3.88, \mathrm{p}=.62)$. As for teachers' responses for the Occupational Professionalism Scale, professional awareness has the highest average $(x=4.32)$, while the lowest average was found in the personal development dimension $(x=3.48)$. Taking standard deviations into consideration, the most homogeneously distributed dimension is professional awareness $(s=.65)$, whereas emotional labor was identified as the most heterogeneously distributed dimension $(s=.74)$. The average of teachers' views for the overall professionalism scale is accepted as "I agree" ( $x=3.86, s=.60)$. Table IV presents results from the Pearson's bidirectional correlation analysis and regression analysis, conducted to determine the relationship between teachers' attitudes towards the teaching profession and their occupational professionalism.

Table IV. Correlation analysis results between teachers' attitudes towards teaching and profession and their occupational professionalism

\begin{tabular}{|c|c|c|c|c|c|c|c|c|c|}
\hline & ذِ & 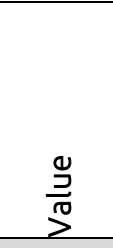 & $\begin{array}{l}\text { तે } \\
\text { O } \\
\text { E⿱ } \\
\text { T } \\
\end{array}$ & 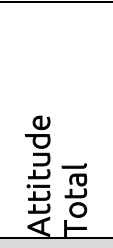 & 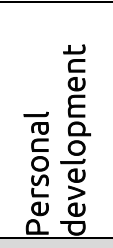 & 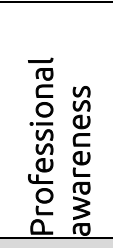 & 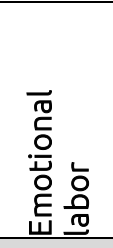 & 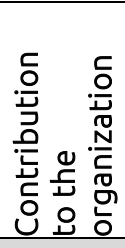 & 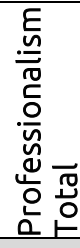 \\
\hline Love & 1 & & & & & & & & \\
\hline Value & $.514 * *$ & 1 & & & & & & & \\
\hline Harmony & $.740 * *$ & $.490 * *$ & 1 & & & & & & \\
\hline Attitude Total & $.972 * *$ & $.665^{* *}$ & $.832 * *$ & 1 & & & & & \\
\hline Personal Development & $.362 * *$ & $.159 *$ & $.285^{* *}$ & $.351 * *$ & 1 & & & & \\
\hline Professional Awareness & $.283^{* *}$ & $.243^{* *}$ & $.327 * *$ & $.318^{* *}$ & $.479 * *$ & 1 & & & \\
\hline Emotional Labor & $.286^{* *}$ & $.175^{* *}$ & $.294^{* *}$ & $.300 * *$ & $.537 * *$ & $.817 * *$ & 1 & & \\
\hline Contribution to the Organization & $.933 * *$ & $.530 * *$ & $.654 * *$ & $.910 * *$ & $.401 * *$ & $.284 * *$ & $.268 * *$ & 1 & \\
\hline Professionalism Total & $.338 * *$ & $.214^{* *}$ & $.342 * *$ & $.355^{* *}$ & $.756 * *$ & $.857 * *$ & $.882 * *$ & $.353 * *$ & 1 \\
\hline
\end{tabular}

For the dimensions of the professional attitude scale, the correlation values in Table IV reveal a high correlation between harmony and love $(r=.740)$, while the lowest correlation was found between harmony and value $(r=.490)$. As for the dimensions of professionalism, the relationship between emotional labor and contribution to the organization was the highest of all $(r=.817)$, while a low correlation was found between contribution to the organization and emotional labor $(r=.514)$. 
The correlations between teachers' attitudes towards the teaching profession and their occupational professionalism levels showed a positive, medium and significant relationship $(r=.355)$. This may be interpreted to mean that occupational professionalism will increase when teachers' attitudes towards the profession improve. With regard to the correlations between dimensions, the highest correlation was found between love and contribution to the organization $(r=.933)$, and the lowest correlation was observed between personal development and value ( $r=.159)$. This may stem from the fact that teachers' contributions to the organization and their love for the teaching profession will increase in correlation; hence, their teaching professionalism also improves.

\subsection{Findings Regarding the Fourth Research Question}

A regression analysis was conducted to determine whether teachers' attitudes towards the teaching profession are a predictor of occupational professionalism and the results are presented in Table V.

Table V. Regression Analysis Results for the Prediction of Teachers' Occupational Professionalism based on Attitudes towards the Teaching Profession

\begin{tabular}{lccccccc}
\hline \multicolumn{1}{c}{ Variable } & B & ShB & $\beta$ & $t$ & P & Pearson Correlation & Partial Correlation \\
\hline Constant & 2.532 & .221 & - & 11.442 & .000 & - & - \\
Professional Attitude & .343 & .056 & .355 & 6.090 & .000 & .355 & .355 \\
\hline
\end{tabular}

$\mathrm{R}=.355 \quad \mathrm{R} 2=126 \quad \mathrm{~F}(1.257)=37.086 \quad \mathrm{P}=.000$

Table $\mathrm{V}$ illustrates a significant effect of teachers' professional attitude scores on their occupational professionalism scores $(F(1.257)=37.08, p=.000)$. In other words, it is most likely to suggest that teachers' professional attitude scores predict their occupational professionalism scores. The regression analysis result shows that professional attitude scores explain $13 \%$ of the total variance related to occupational profession.

\section{Results and discussion}

This research has examined the relationship between teachers' attitudes towards the teaching profession and their occupational professionalism. The research results revealed a positive, medium-level relationship between teachers' attitudes towards the teaching profession and their occupational professionalism. When the findings for the first research question were analyzed, it was found that teachers mostly "agree" about the general attitude scale of the teaching profession.

As far as dimensions are concerned, the dimension that has the highest average and "I am fully competent" score is value; the lowest average is in "I agree" in terms of harmony. Likewise, teachers mostly responded "I agree" for the love dimension. The positive relationship between teachers' attitudes towards the teaching profession and their occupational professionalism is consistent with a study conducted by Cheng (1996) that examined the relationship between teachers' professionalization in teaching, the education process, teachers' professional attitude, and the organizational structure of the school, and found a positive relationship between students' effective learning outcomes and teachers' professionalization.

In parallel with the current study, Cheng (1996) showed an increase in positive attitude towards the teaching profession as the level of teacher professionalism improves. A similar result was found in a study by Rimm-Kaufman and Sawyer (2004), who concluded that teachers are more likely to develop a positive attitude towards their colleagues, students, and the school as their level of professionalism increases.

The present study also points to a significant, medium-level relationship between teachers' attitudes towards the teaching profession and levels of occupational professionalism. This result is consistent with Ahmad et al. (2013). Sandikci and Oncu (2013) concluded that there is a positive and medium-level 
correlation between physical education and other prospective teachers' competency perceptions and their attitudes towards the teaching profession.

As regards the second research question, teachers' views regarding the overall professionalism scale are at the level of "I agree". Teachers' responses to the dimensions have shown that occupational sensitivity has the highest average, at the level of "I totally agree", whereas personal development has the lowest average, at the level of "I agree". Teachers responded to the dimensions of contribution to the organization and emotional labor at the level of "I agree".

For the third research question, the relationship between teachers' attitudes towards the teaching profession and occupational professionalism was examined. Accordingly, a significant positive, mediumlevel relationship was identified between teachers' attitudes towards the profession and occupational professionalism. This may derive from the fact that teachers' occupational professionalism will increase as their attitudes towards the teaching profession develop. This result is in line with Snoek (2010) view that there is a close relationship between professionalism in teaching and attitude towards the teaching profession.

A study by Ayik and Atas (2014) reported that teachers' attitudes towards the teaching profession are a significant predictor of their teaching motivation. However, Bumen and Ozaydin's (2013) study on the relationship between teachers' self-efficacy and their attitudes towards the teaching profession is not consistent with the results of this study, as it was found that teachers' attitudes towards the profession do not differ despite an increase in their self-efficacy beliefs. Usta and Korkmaz (2010) have reported that a positive perception by teachers of the use of technology in education resulted in a positive effect on teachers' attitudes towards the teaching profession.

Based on the regression analysis conducted in order to identify whether teachers' attitudes towards the profession predict their occupational professionalization levels, a significant effect was found on teachers' occupational professionalization scores $(F(1.257)=37.08, p=.000)$. The research results also revealed that the scores of teachers' attitudes towards the teaching profession explain $13 \%$ of the total variance related to occupational professionalism. Snoek's (2010) research findings support this study insofar as there is a close relationship between professionalism in teaching and attitude towards the teaching profession.

In the literature related to these findings, Кramer (2003) reported a close relationship between professionalism in teaching and attitude towards the teaching profession. In addition, some studies have analyzed the relationship between attitudes towards the teaching profession and different variables; the results show that the scores of teachers' attitudes towards the profession are a significant predictor of occupational professionalism. A study conducted by Oguz (2013) pointed to a relationship between prospective teachers' attitudes towards the teaching profession and classroom management styles, which significantly predicts course management.

In a study conducted by Demirtas et al. (2011), a positive but low correlation was identified between prospective teachers' attitudes towards the teaching profession and their self-efficacy perceptions. One such study conducted by Recepoglu (2013) has revealed a significant positive, medium-level correlation between teachers' attitudes towards the teaching profession and a life satisfaction scale; life satisfaction significantly predicts attitudes towards the teaching profession.

Based on the research findings, teachers' professional attitudes may be said to be a significant predictor of teachers' occupational professionalism.

\section{Reccomendations}

This research has determined that teachers' attitudes towards the teaching profession are a significant predictor of their occupational professionalism. Based on the research findings, the following 
recommendations are provided:

1. Studies should be carried out on how teachers can develop far more positive attitudes towards their profession.

2. The level of professionalism in the teaching profession should be tested based on different variables.

3. Qualitative studies should be conducted on the obstacles to teachers' occupational professionalism.

4. It may be wise to compare the professionalism levels of teachers working in different disciplines.

5. Studies should be conducted to support the professional development of teachers.

6. Since this research is limited to teachers working at state schools, it may be worthwhile to carry out studies with teachers in private schools.

\section{References}

Adiguzel, O., Tanrıverdi, H., \& Ozkan, D. S. (2011). Mesleki profesyonellik ve bir meslek mensupları olarak hemşireler örneği [Occupational professionalism and the case of nurses as members of the profession]. Journal of Administrative Sciences, 9(2), 239-259.

http://acikerisim.lib.comu.edu.tr:8080/xmlui/handle/COMU/783

Agcam, R., \& Babanoglu, P. (2016). An investigation on EFL teachers' attitude toward teaching profession. Higher Education Studies, 6(3), 21-31. https://doi.org/10.5539/hes.v6n3p21

Ahmad, I., Said, H., Zeb, A., Ullah, S., \& Rehman, K. (2013). Effects of professional attitude of teachers on their teaching performance: Case of government secondary school teachers in Malakand Region, Khyber Pakhtunkhwa, Pakistan. Journal of Educational and Social Research, 3(1), 25-33. https://www.mcser.org/images/stories/jesr.january.2013/iabal.ahmad-effects.pdf

Anderson, L. W. (1988). Measurement of Attitude. In J. Keeves (Ed.), Educational Research, Methodology, and Measurement: An international Handbook (pp. 885-895). Pergamon.

Ayik, A., \& Atas, Ö. (2014). The relationship between pre-service teachers' attitudes towards the teaching profession and their motivation to teach. Journal of Educational Sciences Research, 4(1), 25-43.

Balci, A. (2001). Research in social sciences: Methods, techniques and principles. Pegem Publishing.

Bumen, N. T., \& Ozaydin, T. E. (2013). Changes on teacher self-efficacy and attitudes towards teaching profession from candidacy to induction. Education and Science, 38(169), 109-125.

https://www.researchgate.net/publication/287476993 Changes on Teacher Self-

Efficacy and Attitudes towards Teaching Profession from Candidacy to Induction

Buyukozturk, S. (2010). Data analysis handbook for social sciences. Pegem Publishing.

Can, A. (2014). Quantitative data analysis in the scientific research process with sPSS. Pegem Publishing.

Cansoy, R., \& Parlar, H. (2017). Okul gelisiminin bir yordayıcısı olarak öğretmen profesyonelizmi [Teacher professionalism as a predictor of school improvement]. Ahi Evran Universitesi Kırshir Egitim Fakültesi Dergisi (KEFAD), 18(1), 269-289. http://hdl.handle.net/11467/3167

Carr, D. (2005). Professionalism and ethics in teaching. Routledge. 
Cetin, A., \& Dogan, A. (2018). Bilim ve sanat merkezlerinde görev yapan matematik öğretmenlerinin karşılaştıkları sorunlar [Problems that mathematics teachers encounter in science and art centers]. Ankara University Faculty of Educational Sciences Journal of Special Education, 19(4), 615-641.

https://doi.org/10.21565/ozelegitimdergisi.370355

Çetin, S. (2006). Establishment of the Profession of Teaching Attitude Scale (The study for validity and confidence). Gazi University Journal of Industrial Arts Education Faculty, 18, 28-37.

Cheng, Y. C. (1996). Relation between teachers' professionalism and job attitudes, educational outcomes, and organizational factors. The Journal of Educational Research, 89(3), 163-171.

https://doi.org/10.1080/00220671.1996.9941322

Cohen, D. K., \& Hill, H. C. (2000). Instructional policy and classroom performance: The mathematics reform in California. Teachers College Record, 102(2), 294-343.

https://www.cpre.org/sites/default/files/researchreport/780 гг39.pdf

Cokluk, O., Sekercioglu, G., \& Buyukozturk, S. (2010). Multivariate statistics: SPSS and LISREL applications for social sciences. Pegem Publishing.

Demircioglu, E., \& Ozdemir, M. (2014). Fen ve Edebiyat Fakültesi Öğrencilerinin Öğretmenlik Mesleğine Yönelik Tutumlarının Çeşitli Değişkenlere Göre İncelenmesi [Investigation of science and literature faculty students' attitudes towards teaching profession according to various variables]. Mersin Üniversitesi Eğitim Fakültesi Dergisi, 10(3) , 110-122.

https://dergipark.org.tr/en/pub/mersinefd/issue/17395/181845?publisher=mersin

Demirel, O., \& Un, K. (1987). Dictionary of educational terms. Safak Printing House.

Demirtas, H., Comert, M., \& Ozer, N. (2011). Pre-service teachers' self-efficacy beliefs and attitudes towards profession. Education and Science, 36(159), 96-111.

https://www.researchgate.net/publication/259196210 Pre-Service Teachers' Self-

Efficacy Beliefs and Attitudes towards Profession

Evans, L. (2011). The 'shape' of teacher professionalism in England: Professional standards, performance management, professional development and the changes proposed in the 2010 White Paper. British Educational Research Journal, 37(5), 851-87. https://doi.org/10.1080/01411926.2011.607231

Evetts, J. (may, 2012). Professionalism in turbulent times: Changes, challenges and opportunities. Propel International Conference. Stirling.

Gökcora, I. H. (2005). Concepts of professional and professionalism, concerning our social lives and the Turkish scientific world. The World of Knowledge, 6(2), 237-250.

Guskey, T. R. (1986). Staff development and the process of teacher change. Educational Researcher, 15(5), 5-12. https://doi.org/10.3102/0013189X015005005

Hanlon, G. (1998). Professionalism as enterprise: Service class politics and the redefinition of professionalism. Sociology, 32(1), 43-63. https://doi.org/10.1177/0038038598032001004

Helterbran, V. R. (2008). Professionalism: Teachers taking the reins. The Clearing House. A Journal of Educational Strategies, Issues and Ideas, 81(3), 123-127. https://doi.org/10.3200/TCHS.81.3.123-127

Kagitcibasi, C., \& Cemalcilar, Z. (2014). Dünden bugüne insan ve insanlar sosyal psikolojiye giriş [Human and humans then and now. Introduction to Social Psychology]. Evrim Publishing House. 
Karasar, N. (2005). Scientific research method. Nobel Publication Distribution.

Kaya, A., \& Buyukkasap, E. (2005). Physics student teachers' profiles, attitudes and anxiety toward teaching profession: An Erzurum sample. Kastamonu Education Journal, 13(2), 367-380.

Kosar, S. (2015). Ogretmen profesyonelizminin yordayıcıları olarak okul mudurune güven ve öz yeterlik [Trust in school principal and self-efficacy as predictors of teacher professionalism]. Egitim ve Bilim, 40(181), 255-270. http://dx.doi.org/10.15390/EB.2015.4562

Kramer, P. (2003). The ABC's of professionalism. Kappa Delta Pi Record, 40(1), 22-25. https://doi.org/10.1080/00228958.2003.10516409

Latchanna, G., \& Dagnew, A. (2009). Attitude of teachers towards the use of active learning methods. Ejournal of All India Association for Educational Research, 21(1).

McCulloch, G., Helsby, G., \& Knight, P. (2000). The politics of professionalism: Teachers and the curriculum. A\&C Black.

McMillan, J. H., \& Schumacher, S. (2006). Research in education: Evidence-based inquiry. Pearson Education.

OECD. (2016). Supporting teacher professionalism: Insights from TALIS 2013. Autor.

Oguz, E. (2013). Öğretmen adaylarının sınıf yönetimi stilleri ile öğretmenlik mesleğine ilişkin tutumları arasındaki ilişki [The relationship between classroom management styles of pre-service teachers and their attitude to the teaching profession]. Trakya University Journal of Education, 3(2), 12-20.

https://dergipark.org.tr/en/download/article-file/200338

Recepoglu, E. (2013). Öğretmen adaylarının yaşam doyumları ile öğretmenlik mesleğine ilişkin tutumları arasındaki ilişkinin incelenmesi [Analyzing the relationship between prospective teachers' life satisfaction and attitudes concerning the teaching profession]. Hacettepe University Journal of Education, Special issue, 1, 311-326. http://www.efdergi.hacettepe.edu.tr/yonetim/icerik/makaleler/297-published.pdf

Rimm-Kaufman, S. E., \& Sawyer, B. E. (2004). Primary-grade teachers' self-efficacy beliefs, attitudes toward teaching, and discipline and teaching practice priorities in relation to the "responsive classroom" approach. The Elementary School Journal, 104(4), 321-341. https://www.jstor.org/stable/3202945

Robson, J. (2006). Teacher professionalism in further and higher education: Challenges to culture and practice. Routledge.

Sandikci, M., \& Oncu, E. (2013). Beden eğitimi ile diğer alanlardaki öğretmen adaylarinin öğretmenlik mesleğine ilişkin yeterlik algilari ve tutumlarinin belirlenmesi ve karşilaştirilmasi. [Determination and comparison of physical education and other pre-service teachers' self-efficacy beliefs and attitudes toward the teaching profession]. Pamukkale Journal of Sport Sciences, 4(1), 135-151.

https://dergipark.org.tr/en/download/article-file/191780

Snoek, M. (2010). Theories on and concepts of professionalism of teachers and their consequences for the curriculum in teacher education. http://kennisbank.hva.nl/document/477245

Snoek, M., Swennen, A., \& van der Klink, M. (2011). The quality of teacher educators in the European policy debate. Professional Development in Education, 37(5), 1-18 
Tichenor, M. S., \& Tichenor, J. M. (2005). Understanding Teachers' Perspectives on Professionalism. Professional Educator, $27(1$ \& 2), 89-95. https://files.eric.ed.gov/fulltext/EJ728484.pdf

Unal, L. I. (2011). Öğretmenliğe ve öğretmen yetiştirmeye ilişkin ekonomi politik bir çözümleme [An economic political analysis of teacher education and teacher training]. In Songul Aynal Kilimci (Ed.), Teacher Training Book in Turkey. Pegem Academy Publications.

Unsal, S., Agcam, R., \& Korkmaz, F. (2017). Exploring teaching profession from a sociological perspective: Evidence from Turkey. Universal Journal of Educational Research 5(5): 874-880.

http://www.hrpub.org/journals/article info.php?aid=5960

Usta, E., \& Korkmaz, O. (2010). Pre-service teachers' computer competencies, perception of technology use and attitudes toward teaching career. International Journal of Human Sciences, 7(1), 1335-1349.

https://www.j-humansciences.com/ojs/index.php/IJHS/article/view/1281

Ustuner, M. (2006). Öğretmenlik mesleğine yönelik tutum ölçeğinin geçerlik ve güvenirlik çalışması [Reliability and validity study of an attitude scale for the teaching profession]. Educational Administration: Theory and Practice, 45(45), 109-127.

Yakar, L., \& Yelpaze, ì. (2019). Öğretmen yetiştiren tüm programlardaki öğrencilerin öğretmenlik mesleğine yönelik tutum ve öz-yeterlik algilarinin incelenmesi [Attitudes toward the teaching profession and teacher self-efficacy beliefs of students in teacher training programs]. Pamukkale University Journal of Education 47, 107-129. https://dergipark.org.tr/tr/pub/pauefd/issue/48574/473678

Yilmaz, K., \&Altinkurt, Y. (2014). Öğretmenlerin mesleki profesyonelliği ölçeği geçerlik ve güvenirlik çalışması [Validity and reliability study for the Occupational Professionalism of Teachers Scale (OPTS)]. International Journal of Human Sciences, 11(2), 332-345. https://www.j-humansciences.com/ojs/ index.php/IJHS/article/view/2967

Yirci, R. (2017). Ogretmen profesyonelliginin onündeki engeller ve cözüm onerileri [Barriers to teacher professionalism and suggestions for solutions]. Ahi Evran Universitesi Kırsehir Egitim Fakültesi Dergisi (KEFAD), 18(1), 503-522. 